\title{
Temperature analysis of driver and optical behavior of LED lamps
}

\section{Análise da temperatura de driver e comportamento óptico de lâmpadas LEDs}

Emerson Roberto Santos ${ }^{1,2,3, *}$ (D), Maurício Vicente Tavares ${ }^{4}$, Antonio Celso Duarte ${ }^{3,4}$ (D), Helio Akira Furuya ${ }^{4}$, Elvo Calixto Burini Junior ${ }^{5}$ (D)

1. Universidade de São Paulo - Escola Politécnica - Engenharia Metalúrgica e de Materiais - São Paulo (SP), Brazil.

2. Laboratório SuperCriativo - São Paulo (SP), Brazil.

3. Faculdade de Tecnologia de São Paulo - Centro de Inovações - São Paulo (SP), Brazil.

4. Faculdade de Tecnologia de São Paulo - Microeletrônica - São Paulo (SP), Brazil.

5. Universidade de São Paulo - Instituto de Energia e Ambiente - São Paulo (SP), Brazil.

Correspondence author: cientistaemersonsantos@gmail.com

Section Editor: Maria Lúcia Pereira da Silva

Received: Aug 30, 2021 Approved: Sep 9, 2021

\begin{abstract}
This exploratory study was carried out with the objective to know the optical behavior of light-emitting diode (LED) lamps used and the temperature reached by electronic components that compose the driver (electronic circuit situated inside the body LED lamp) responsible to convert electrical alternating current from power line to direct current to operate the LED devices. Then, two different experiments were carried out with LED lamps. In the first experiment, 131 LED lamps used were chosen randomly and bought from household appliances store (bargain market product) presenting different nominal powers, 8, 10, 12 and 15 watts. All LED lamps were polarized at the power line at $127 \mathrm{~V}$ and revealed different optical behaviors, such as: not turn-on; flashing light (as strobe effect); flashing light (as strobe effect) with high intensity (more intense than normal); flashing light (as strobe effect) with low intensity (less intense than normal); fast turnon and turn-off only; and turn-on with low intensity of light (less intense than normal). The hypothesis for these behaviors can be attributed by three different behaviors: in lamps not turn-on, this failure can be attributed for dark spots that are created on the surface of LED device. In these lamps, all LED devices are electrically connected in serial. When a LED is inoperative, the electrical current is interrupted for all LED devices; damage to the electronic components caused by internal high temperature confined inside the lamp body during the operation causing electrical oscillations, as observed from different behaviors from flashing light, flashing light with high intensity, flashing light with low intensity and fast turn-on and turn-off only; swelling of the electrolytic capacitors causing low energy storage and varying the electrical current flow, the electrical current for other electronic components altered the normal optical behavior of the LED lamps. In the second experiment, the temperatures of electronic components located in driver were obtained out of body lamp revealing: from 33 (lowest temperature attributed to inductor) to $52.5^{\circ} \mathrm{C}$ (highest temperature attributed to electrolytic capacitor). These temperature values represent the ideal or normal condition of operation for electronic components, but, when they are operating inside the lamp body, the found temperature values increased considerably. This characteristic can be better evidenced by strong color change (caused by accumulative temperature during the elapsed days used) on the printed circuit board used in the driver.
\end{abstract}

KEYWORDS: LED lamp, Temperature, Lifetime, Dark spot, Driver. 


\section{RESUMO}

Este estudo exploratório foi realizado com o objetivo de conhecer o comportamento óptico de lâmpadas de diodo emissor de luz (LED) usadas e a temperatura atingida pelos componentes eletrônicos que compõem o driver (circuito eletrônico situado no interior do corpo da lâmpada LED) responsável pela conversão da corrente elétrica alternada da linha de energia em corrente elétrica contínua para funcionar os dispositivos LED. Em seguida, dois experimentos diferentes foram realizados com lâmpadas LED. No primeiro experimento, 131 lâmpadas LED usadas foram escolhidas aleatoriamente e compradas em loja de eletrodomésticos (mercado de produto de pechincha) apresentando diferentes potências nominais, 8, 10, 12 e 15 Watts. Todas as lâmpadas LED foram polarizadas na rede elétrica em $127 \mathrm{~V}$ e revelaram diferentes comportamentos ópticos: não acendem; luz intermitente (como efeito estroboscópico); luz intermitente (como efeito estroboscópico) com alta intensidade (mais intensa que a normal); luz intermitente (como efeito estroboscópico) com baixa intensidade (menos intensa que a normal); rápido liga-desliga apenas; e liga com baixa intensidade de luz (menos intensa que a normal). Há três diferentes hipóteses para esses comportamentos: em lâmpadas que não acendem, essa falha pode ser atribuída a manchas escuras que são criadas na superfície do dispositivo LED. Nessas lâmpadas, todos os dispositivos LED estão conectados eletricamente em série. Quando um LED está inoperante, a corrente elétrica é interrompida para todos os dispositivos LED; danos aos componentes eletrônicos causados por alta temperatura interna confinada dentro do corpo da lâmpada durante a operação, causando oscilações elétricas, conforme observado pelos diferentes comportamentos de luz intermitente, luz intermitente com alta intensidade, luz intermitente com baixa intensidade e rápido liga-desliga apenas; estufamento dos capacitores eletrolíticos, causando baixo armazenamento de energia, variando o fluxo de corrente elétrica para outros componentes eletrônicos e alterando o comportamento óptico normal das lâmpadas LED. No segundo experimento, as temperaturas dos componentes eletrônicos localizados no driver foram obtidas fora do corpo da lâmpada, revelando de 33 (menor temperatura atribuída ao indutor) até $52,5^{\circ} \mathrm{C}$ (maior temperatura atribuída ao capacitor eletrolítico). Esses valores de temperatura representam a condição ideal ou normal de operação dos componentes eletrônicos, mas, quando estão operando dentro do corpo da lâmpada, esses valores de temperatura encontrados aumentam consideravelmente. Essa característica pode ser mais bem evidenciada pela forte mudança de cor (causada pelo acúmulo de temperatura durante os dias de uso) na placa de circuito impresso do driver.

PALAVRAS-CHAVE: Lâmpada LED, Temperatura, Tempo de vida, Mancha escura, Driver.

\section{INTRODUCTION}

Light-emitting diode (LED) is a little semiconductor electronic device mounted with different materials known as $\mathrm{p}$ and $\mathrm{n}$ types that transforms electrical energy in light ${ }^{1,2}$. The electrical behavior showed by I (current) vs. V (voltage) of LED device (similar as diode) can be divided by two different steps, when it is directly polarized ${ }^{3,4}$.

1. The elevation of the voltage applied to LED device, it presents resistive (or insulator) electrical behavior;

2. It is evidenced by electrical semiconductor characteristic increasing the electrical current with low increase of the voltage applied obtaining the threshold voltage (or VTh) of LED device ${ }^{4,5}$.

Each color emission is represented by different threshold voltages considering the same LED type, as showed by Fig. 1.

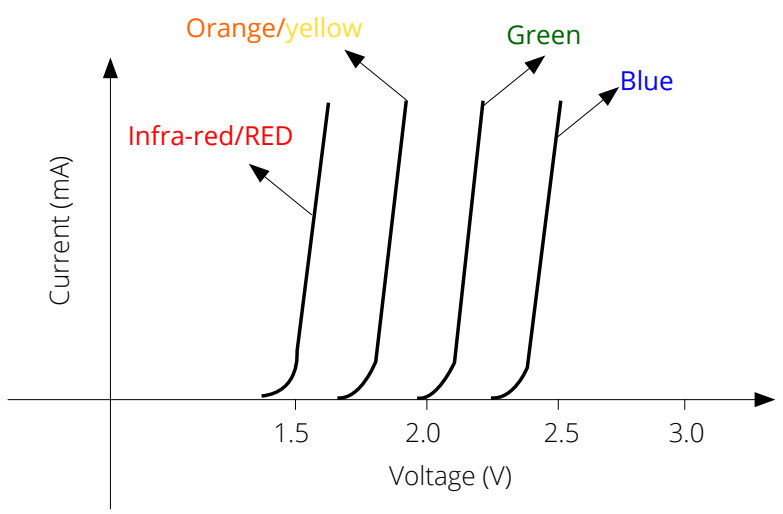

Figure 1: Current vs. voltage and threshold voltage for light-emitting diode (LED) with different color emissions. 
The explanation to the different color light emissions is related by Eq. 14,6:

$$
E_{g}=\frac{h c}{\lambda}
$$

In which $E_{g}$ : the bandgap energy (electron-volt); $\lambda$ : the wavelength of light emission; h: the Planck's constant (6.62607004.10-34 $\left.\mathrm{m}^{2} \cdot \mathrm{kg} / \mathrm{s}\right)$; c: the light speed $(299.792 .458 \mathrm{~m} / \mathrm{s})$.

Due to $\mathrm{h}$ and $\mathrm{c}$ to be constants, the wavelength emitted by LED will define the emission color that is dependent on bandgap energy $\left(E_{g}\right)$. Then, in general terms, the wavelength emitted by LED is directly related to the gap energy band. The recombination of negative and positive charges that are created by different material $n$ and $p$ types inside the LED generates the passage from conduction band to the valence band (Fig. 2), generating the light emission, when the LED is directly polarized?

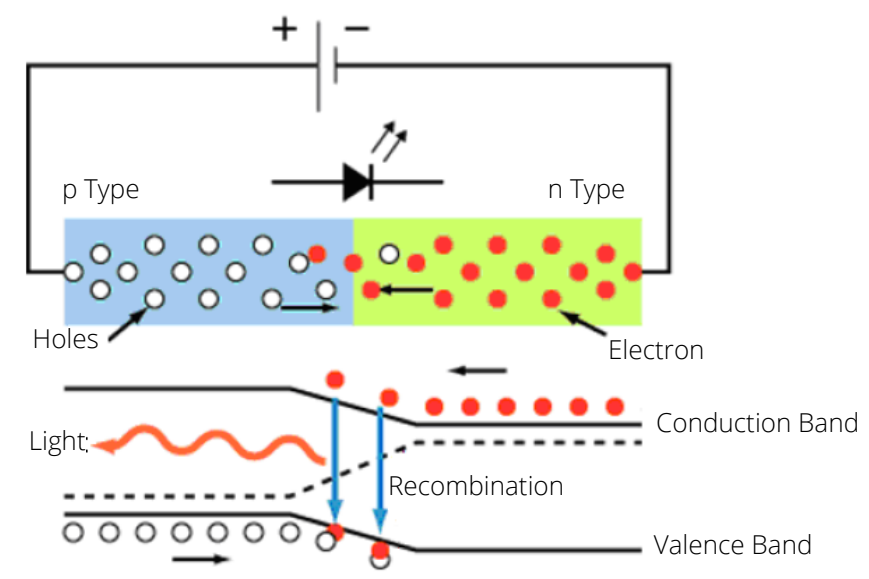

Figure 2: Material with $\mathrm{p}$ and $\mathrm{n}$ types and energy bands: conduction, valence and charges recombination. Source: adapted from Marteleto?.

The LED devices emit light with defined wavelength inside the visible light spectrum (Fig. 3) ${ }^{8}$.

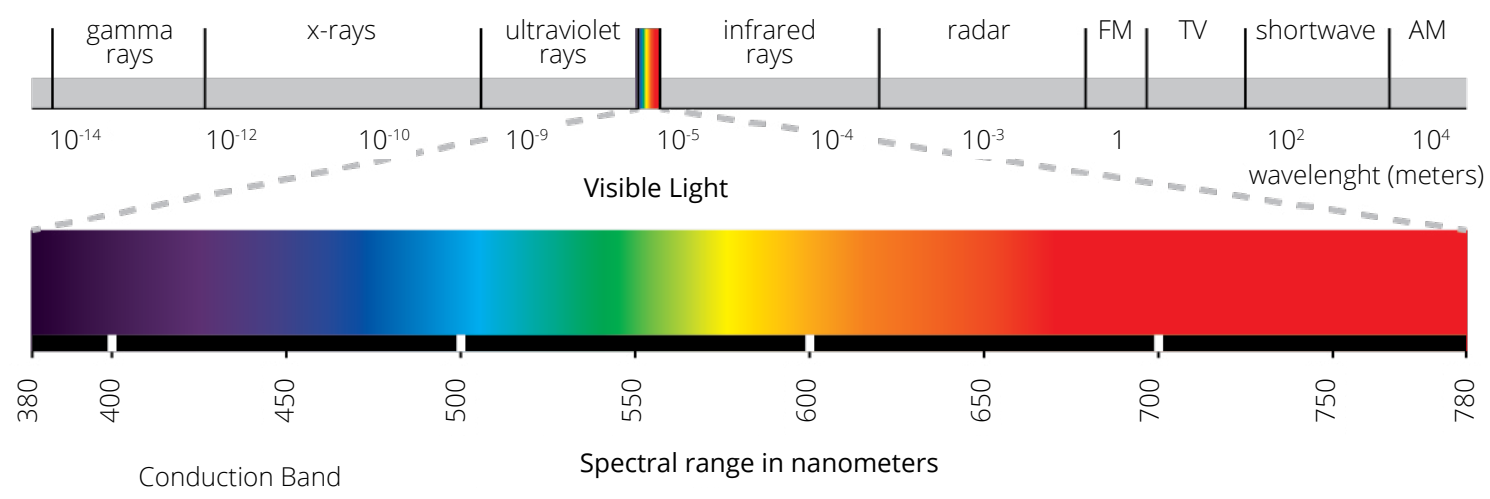

Figure 3: Visible light spectrum with different wavelengths for different emitting colors.

$$
\text { Source: Hortilux }{ }^{8} \text {. }
$$

In comparison of all source lights produced by human, the LED lamps have presented the most significant performance related to the efficiency. Some characteristics have been revealed by LED lamps, as: lower energy consumption, easy dimerization, good mechanical resistance (uses no glass), low voltage operation, ecological, green engineering, low luminosity depreciation, color dynamic control, fast turn-on, variable intensity control, vivid and saturated color production, directional light flux and uses no ballast ${ }^{9-11}$.

But problems are frequently found, for example, variation of the light intensity, affecting the normal performance of LED lamps and compromising directly the luminotechnical characteristics, known such as ${ }^{12}$ :

- Luminous flux: is the amount of light produced and emitted by source light for all directions. The unit is lumen (or Im); 
- Illuminance: is the division between the luminous flux and the area to be illuminated. For example, illuminance of 1 lux occurs when the luminous flux of $1 \mathrm{Im}$ is uniformly distributed on an area of $1 \mathrm{~m}^{2}$. It is also possible to say that the illuminance is the luminous flux that is projected on the area, or the amount of light that reaches any surface. The unit is lux (or Ix);

- Luminous intensity: is the amount of light emitted by source light in a determined direction. A light source emits the luminous flux in all directions with different intensities. Then, the luminous intensity is related to the light beam. The unit is candle (or cd);

- Luminous efficacy: is the amount of luminous flux emitted by source light divided by power consumed of energy line (Eq. 2). The unit is the $\mathrm{Im} / \mathrm{W}$.

$$
\text { Luminous Efficacy }=\frac{\text { Luminous flux }}{\text { Power }}=\frac{\operatorname{Lumen}(\mathrm{lm})}{\operatorname{Watt}(W)}
$$

- Power factor (PF): is presented by pure number from 0 to 1 (without unit). It represents how much power is necessary to perform a function considering some losses, such as: heat, mechanical movement (in the case of engines) or electrical resistances (generated by intern electronic circuits). The efficiency of light source is related by higher PF, that can be also represented as percentage (\%);

- Correlated color temperature: is the appearance of color light represented by unit Kelvin (K) temperature. There are some well-known temperatures in the literature. The correlated color temperature (CCT) was obtained in 1931 and it is related by chromaticity diagram presented by Commission Internationale de L'Eclairage (CIE). The CCT was obtained by the concept of blackbody heated with different temperatures. When the blackbody is heating, it emits different colors that are related by different wavelengths from red to blue (as represented by electromagnetic spectrum). The sequency of colors emitted with elevation of temperature is described by Planck Locus curve inside the color space established by CIE in 1931'13. Figure 4 brings the chromaticity diagram. In it, it is possible to verify the wavelength values to the pure colors emitted at the edges, for example: $700 \mathrm{~nm}$ to the red color, 520 $\mathrm{nm}$ to the green color and $460 \mathrm{~nm}$ to the blue color (RGB basic colors to reproduce all colors of the rainbow). All monochromatic source lights present an emission color that can be obtained by $x$ and $y$ axis on the chromaticity diagram. The connection of $x$ and $y$ values presents the color emitted by a source light precisely.

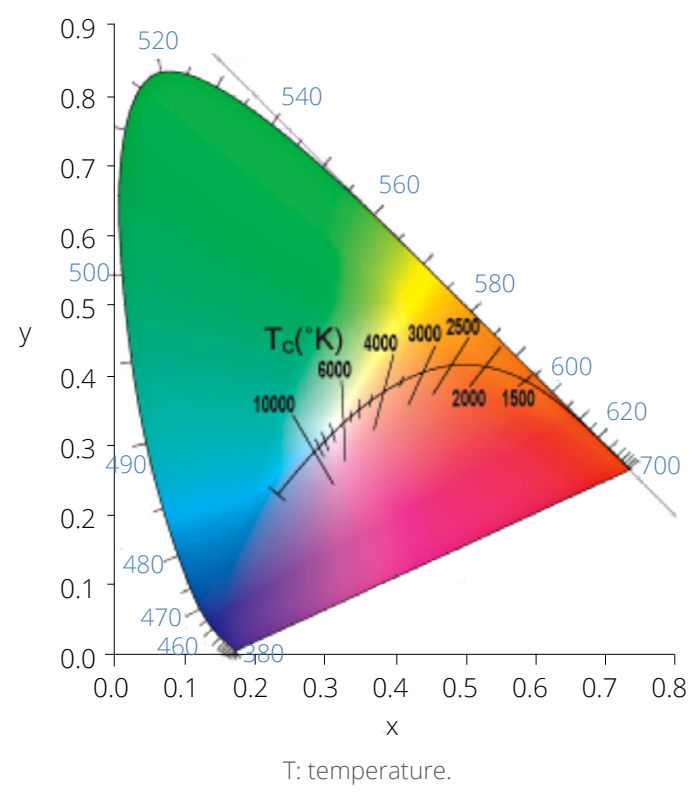

Figure 4: Chromaticity diagram with chromaticity coordinates and Planck Locus curve established by Commission Internationale de L'Eclairage in 1931.

Source: Megaman ${ }^{14}$

- Color rendering index (CRI): is represented by pure number with scale from 0 to 100 (without unit). It is used to measure the fidelity of color that the illumination reflects from objects. The artificial light allows to the human eyes to perceive colors correctly or with similar aspect as obtained by nature light. Sun light (or nature light) is 
cited as source light that produces better color rendering index presenting CRI $=100$, because it reproduces all colors of electromagnetic spectrum visible to the human eyes. The artificial lights that present similar CRI in comparison with sun light are incandescent and halogens (dichroic, for example) lamps. The sodium lamps present the lowest CRI, and this optical characteristic difficults to obtain the real color reflected from objects, presenting $C R I=25$. The values obtained by $C R I$ can be represented also as percentage (\%);

- Electroluminescence: is a technique that reveals the wavelengths irradiated by source lights. For example, Fig. 5 shows the wavelengths of red, green, and blue (RGB) spectra obtained of LEDs from $5 \mathrm{~mm}$. The dominant peaks from $\approx 450 \mathrm{~nm}$ to the blue light, $\approx 563 \mathrm{~nm}$ to the green light and $\approx 654 \mathrm{~nm}$ to the red light reveal that these LED devices present no pure color emitted (due to the large variation related on the peak bases).

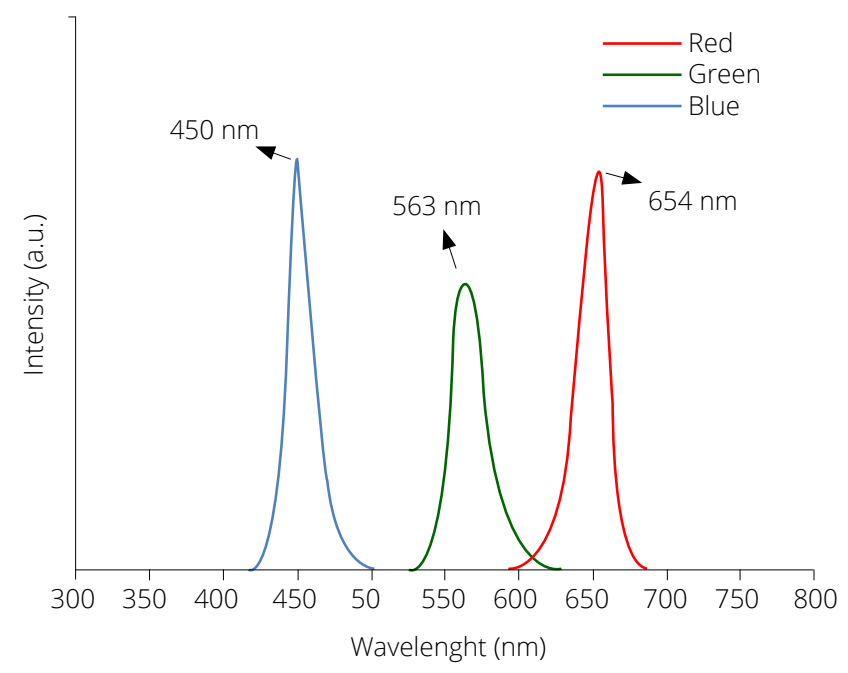

Figure 5: Intensity vs. wavelength of light-emitting diode (LED) with $5 \mathrm{~mm}$ and emission colors: red, green, and blue.

Another example is showed by Fig. 6 to the spectrum obtained of LED with $5 \mathrm{~mm}$ emitting white color, revealing a dominant wavelength peak from $\approx 452 \mathrm{~nm}$, related to the blue color with low intensity, from $\approx 500$ to $\approx 700 \mathrm{~nm}$ (but with large variation of base from blue to red).

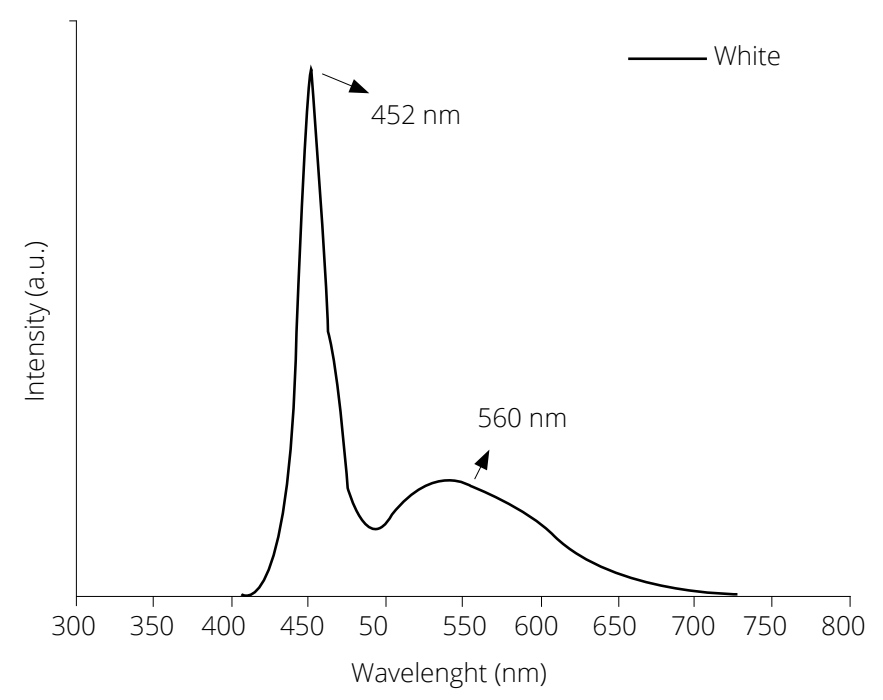

Figure 6: Intensity vs. wavelength for light-emitting diode (LED) with $5 \mathrm{~mm}$ and white.

- Luminance: light emitted by LED can be obtained by two forms, high and low intensity. The emission of light is a factor determinant for each application. For example, if it is necessary to use a LED as an only indicator characteristic (as used in many home appliances), the intense light presented by LED is very different as the one obtained by LED 
used to illumination. The luminance represents the measurement of amount light that cross a surface or that is reflected by it, occurring by an angle defined. The luminance also indicates the amount of brightness light emitted or reflected by a surface. For example, in the displays company, the luminance is used to quantify the brightness on some distinct points on the surface. The unit of luminance is the candle/square meter $\left(\mathrm{cd} / \mathrm{m}^{2}\right)$.

Before deeply knowing the optical characteristics of LED lamps (as described previously), it was necessary to know firstly the most common problems found in these light sources and that directly reflect on their performances (causing changes in these optical characteristics).

So, in this work, two experiments with LED lamps were carried out with the objectives to identify the optical behavior by visualizing from human eyes and report the problems found, and to analyze the temperature of the electronic components used on driver of LED lamps that directly influences the electrical performance and optical characteristics.

\section{MATERIALS AND METHODS}

In this work, two different experiments were carried out:

- Optical visual analyses of 131 LED lamps bought from used household appliances store (bargain product market). The LED lamps manufactured by Briwax company with different powers, 8, 10, 12 and 15 watts, were tested. Each LED lamp was polarized at the power line with 127 volts, and it was observed different optical behaviours;

- Temperature analyses of electronic components from driver were obtained of a new LED lamp of 9 watts with correlated color temperature at 3,600 K and manufactured by Black+Decker company. To measure the temperature, the LED lamp was polarized at the power line by 127 volts, and a multimeter manufactured by Minipa, model ET-2028-A, was used connected by a thermocouple. The sensor tip touched the electronic components in two different positions for each device analysed.

\section{RESULTS}

Tables 1 to 4 show the LED lamps tested with different nominal powers and identified with: problem observed and amount (number of LED lamps tested). The results revealed from three to six different problems, and the most common problem noticed was related to the LED lamps that presented not operation for 65 samples (from total of 131 samples).

Table 1: Light-emitting diode (LED) lamps of Briwax company with 8 W, problem observed and amount (number of LED lamps tested).

\begin{tabular}{cc}
\hline Problem observed for LED lamp of $8 \mathrm{~W}$ & $\begin{array}{c}\text { Amount } \\
\text { (number of LED lamps tested) }\end{array}$ \\
\hline not turn-on & 5 \\
\hline flashing light with low intensity (more intense than the nominal power described) & 1 \\
\hline fast turn-on and turn-off & 1 \\
\hline turn-on with low intensity of light (less intense than the nominal power described) & 1 \\
\hline
\end{tabular}

Table 2: Light-emitting diode (LED) lamps of Briwax company with $10 \mathrm{~W}$, problem observed and amount (number of LED lamps tested).

\begin{tabular}{|c|c|}
\hline Problem observed for LED lamp of $10 \mathrm{~W}$ & $\begin{array}{c}\text { Amount } \\
\text { (number of LED lamps tested) }\end{array}$ \\
\hline turn-on & 2 \\
\hline not turn-on & 27 \\
\hline flashlight (as strobe) & 2 \\
\hline flashing light (as strobe) with low intensity (more intense than the nominal power described) & 5 \\
\hline turn-on with low intensity of light (less intense than the nominal power described & 2 \\
\hline
\end{tabular}


Table 3: Light-emitting diode (LED) lamps of Briwax company with $12 \mathrm{~W}$, problem observed and amount (number of LED lamps tested).

\begin{tabular}{|c|c|}
\hline Problem observed for LED lamp of $12 \mathrm{~W}$ & $\begin{array}{c}\text { Amount } \\
\text { (number of LED lamps tested) }\end{array}$ \\
\hline turn-on & 6 \\
\hline not turn-on & 27 \\
\hline flashing light (as strobe) & 15 \\
\hline flashing light (as strobe) with high intensity (more intense than the nominal power described) & 1 \\
\hline flashing light (as strobe) with low intensity (more intense than the nominal power described) & 7 \\
\hline fast turn-on and turn-off & 1 \\
\hline turn-on with low intensity of light (less intense than the nominal power described) & 1 \\
\hline
\end{tabular}

Table 4: Light-emitting diode (LED) lamps of Briwax company with 15 W, problem observed and amount (number of LED lamps tested).

\begin{tabular}{cc}
\hline Problem observed for LED lamp of 15 W & $\begin{array}{c}\text { Amount } \\
\text { (number of LED lamps tested) }\end{array}$ \\
\hline turn-on & 6 \\
\hline not turn-on & 6 \\
\hline flashing light (as strobe) & 6 \\
\hline flashing light (as strobe) with low intensity (more intense than the nominal power described) & 5 \\
\hline turn-on with low intensity of light (less intense than the nominal power described) & 4 \\
\hline
\end{tabular}

The reason attributed to the LED lamps not normally operate is related to the possible two problems:

- Damage of electronic components from the driver;

- Dark spot on the phosphor layer of LED device (interrupting the current for all LEDs).

\section{DAMAGE OF ELECTRONIC COMPONENTS FROM THE DRIVER}

LED lamps have presented lower lifetime than that described at the packages. In this case, new manufactures of LED lamp (without tradition at the illumination market) have used unknown suppliers of electronic devices (electrolytic capacitors, integrated circuits, resistors, diodes, and surface mounted devices) to assembly of drivers, that are electronic circuits responsible to convert alternating current (AC) in direct current (DC) to operate the LEDs.

Another problem verified is related to the intern temperature inside the body of the LED lamp (Fig. 7), that has caused overheating of the integrated circuit or another electronic component and swelling the electrolytic capacitor (with dryness of the intern dielectric material responsible by storing energy), causing low energy storage and, consequently, influencing the performance of LED lamps.

(a)

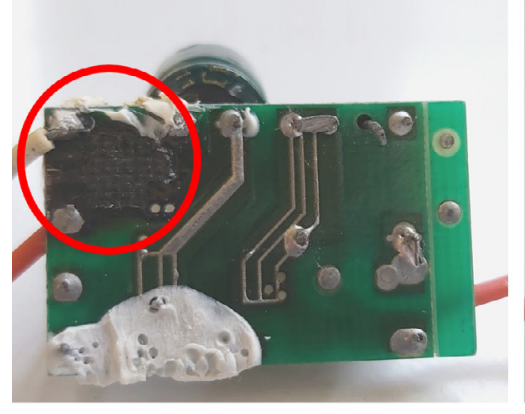

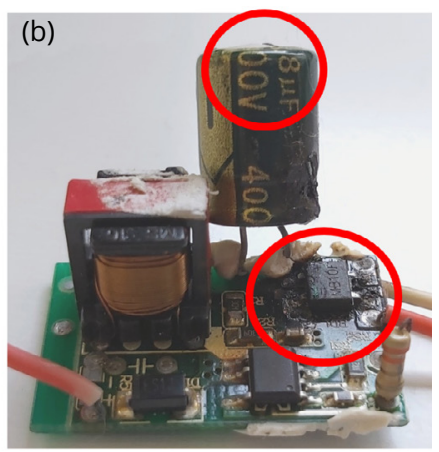

Figure 7: Inoperant driver (electronic circuit) obtained from light-emitting diode (LED) lamp with electronic components damaged. 
As an example, Figs. 8a and 8b show the used LED lamp of 9 watts, correlated color temperature at 3,600 K, and manufactured by Black+Decker company. The intern heat confined inside the body of LED lamp showed a significant influence on the electronic components. This characteristic is very evidenced by color change of the printed circuit board by Figs. $8 \mathrm{a}$ and $8 \mathrm{~b}$ caused by accumulative temperature with the usage time. The extraction of the intern heat is a very important factor to obtain high lifetime to the LED lamps.
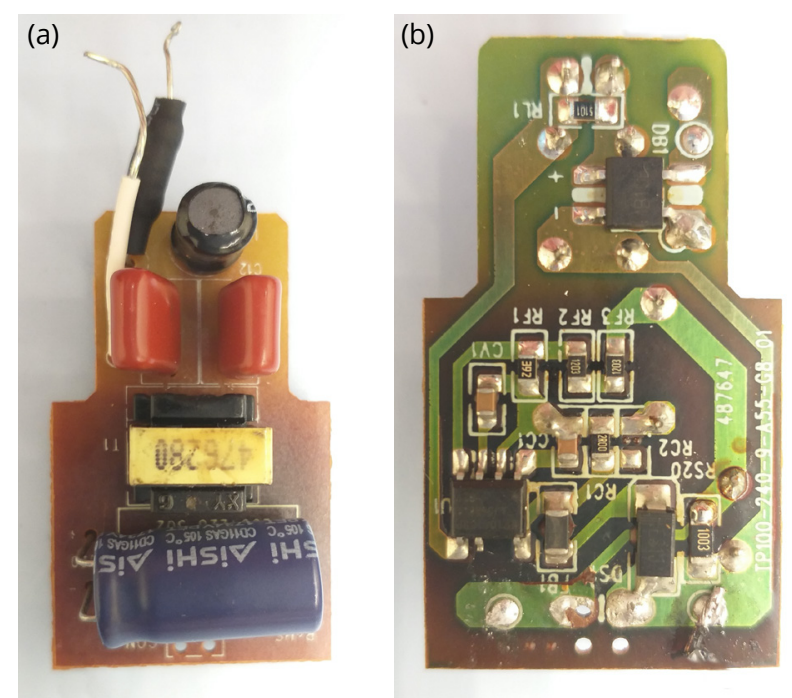

Figure 8: Driver (electronic circuit) obtained from a used light-emitting diode (LED) lamp: (a) up and (b) bottom sides.

Figs. 9a and 9b show the new LED lamp (with same technical characteristics: 9 watts, correlated color temperature at $3,600 \mathrm{~K}$, and manufactured by Black+Decker company) with driver polarized out of LED lamp. The temperature operating found, from 33 (of inductor) to $52.5^{\circ} \mathrm{C}$ (electrolytic capacitor), represents the ideal condition, but when the electronic components are operating inside the lamp these temperature values increase considerably.
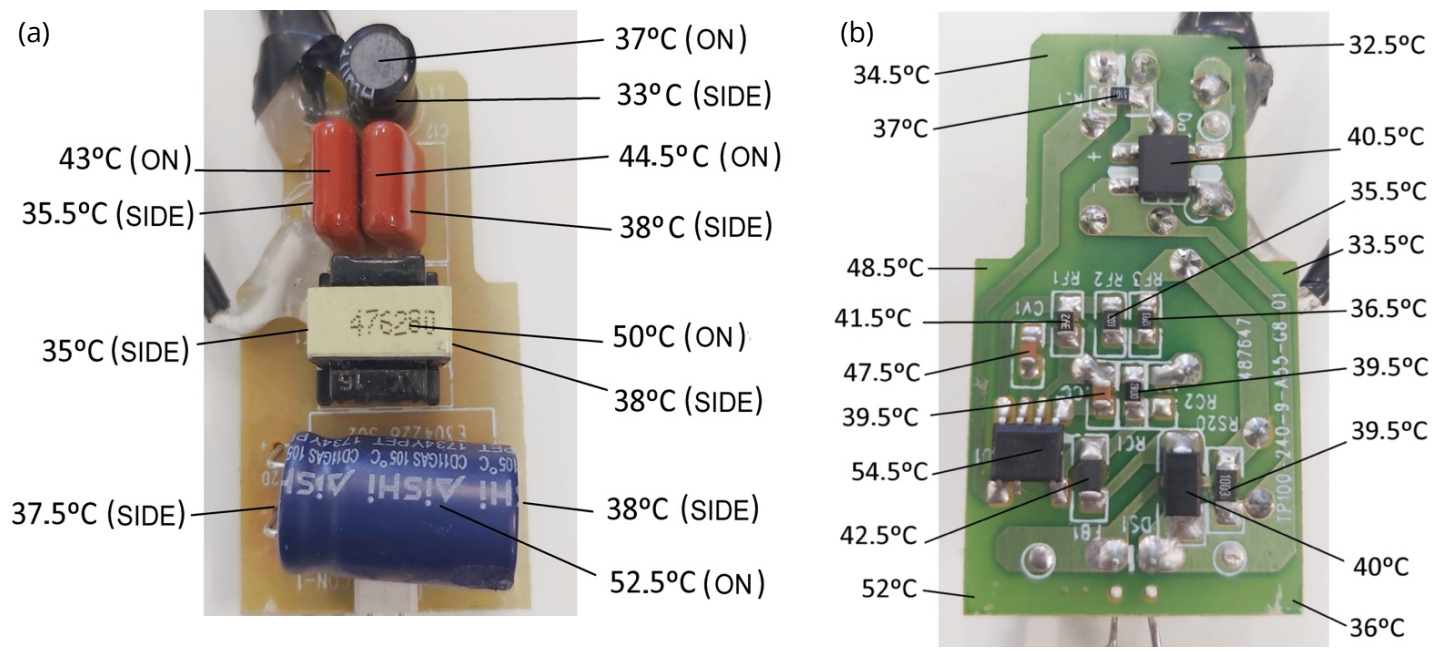

Figure 9: Driver (electronic circuit) obtained from a new light-emitting diode (LED) lamp: (a) up and (b) bottom sides.

\section{DARK SPOT ON THE PHOSPHOR LAYER}

Another very frequent problem observed for LED lamps is related to the appearance of dark spots on the LED device surfaces that are caused by high temperature, $\approx 130^{\circ} \mathrm{C}$, with usage time ${ }^{15}$. The LED devices of lamps are connected electrically in series on the metallic board (used as heat sink). Then, when one LED device presents failure, 
all other devices do not emit light, due to the interruption of the electrical current. The excessive stress caused by high temperatures has presented dark spots on the phosphor layer, causing damage on the surface, as showed by Fig. 10a. On the LED surface and under the phosphor layer, there are three elements (active regions) that are connected in series, as observed by Fig. 10b, polarized (at $7.20 \mathrm{~V}$ and $3.88 \mu \mathrm{A}$ ), to obtain low emission of light.
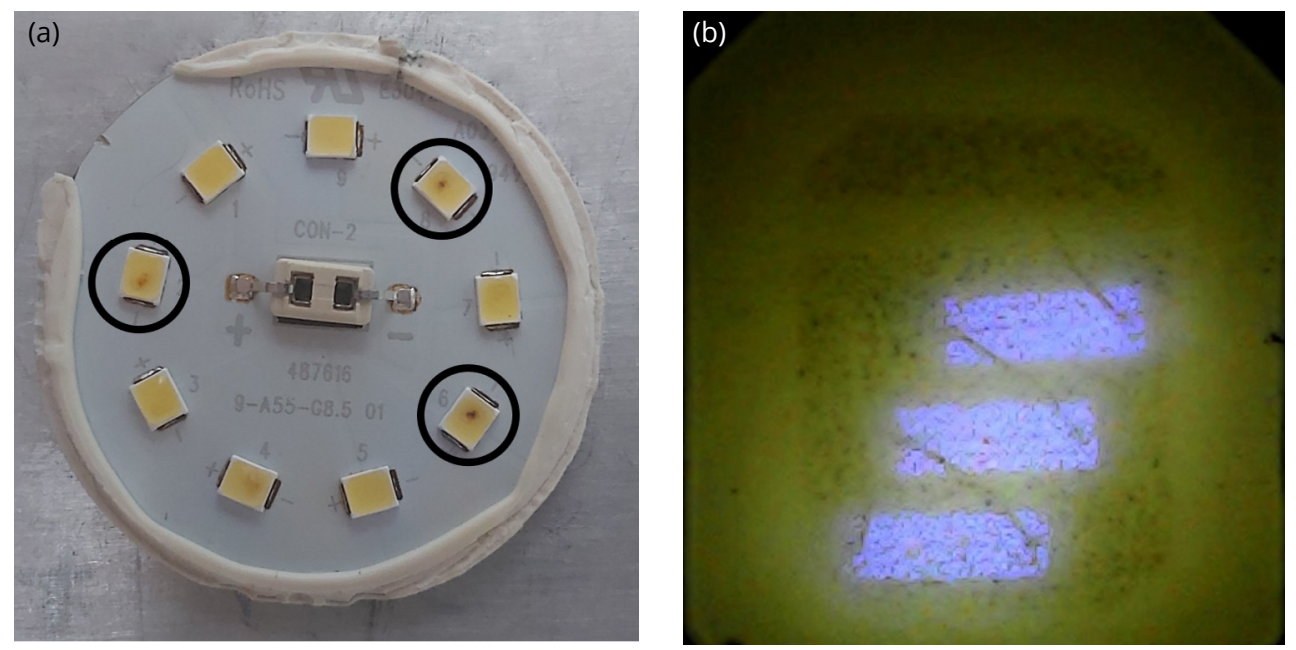

Figure 10: (a) Dark spots formed on the phosphor layer and (b) emission of light with three elements connected in series inside the light-emitting diode (LED).

\section{CONCLUSION}

This exploratory study was carried out with the objective to know the optical behavior of LED lamps used and the temperature reached by electronic components that compose the driver (electronic circuit situated inside the body LED lamp). Then, two different experiments were carried out with LED lamps.

The first experiment was carried out with 131 LED lamps with different powers, 8, 10, 12 and 15 watts. They revealed different optical behaviors, such as: not turn-on; flashing light (as strobe effect); flashing light (as strobe effect) with high intensity (more intense than normal); flashing light (as strobe effect) with low intensity (less intense than normal); fast turn-on and turn-off only; and turn-on with low intensity of light (less intense than normal).

The hypothesis for these behaviors can be attributed by three different behaviors: in lamps not turn-on, this failure can be attributed for dark spots that are created on the surface of LED device. The LED devices are electrically connected in serial. When a presents any kind of failure. This characteristic has been very evidenced (with results not reported here); damage to the electronic components, caused by internal high temperature confined inside the lamp body during the operation causing electrical oscillations, as observed from different behaviors from flashing light, flashing light with high intensity, flashing light with low intensity and fast turn-on and turn-off only; swelling of the electrolytic capacitors causing low energy storage and varying the electrical current flow, the electrical current for other electronic components altered the normal optical behavior of the LED lamps.

In the second experiment, the temperatures of electronic components located in driver were obtained out of body lamp revealing: from 33 (lowest temperature attributed to inductor) to $52.5^{\circ} \mathrm{C}$ (highest temperature attributed to electrolytic capacitor). These temperature values represent the ideal or normal condition of operation for electronic components, but, when they are operating inside the lamp body, the found temperature values increased considerably, because there is bad heatsink. This fact is better evidenced by strong color change (caused by accumulative temperature during the elapsed days used) on the printed circuit board used in the driver.

The high temperature inside the body of LED lamp has caused most failures, as the electronic components are operating above the temperature limit, and this fact has not contributed to the LED lamp reach 25,000 hours, as described at the packages of these products. This high temperature is a problem that needs to be revised by manufactures of LED lamps. The application of holes around the body of LED lamp and also the diffuser has low cost and can be used to better heatsink. 


\section{ACKNOWLEDGMENTS}

The authors thank the Escola Politécnica da Universidade de São Paulo, Engenharia Metalúrgica e de Materiais and Instituto de Energia e Ambiente da Universidade de São Paulo, for providing installations and equipments.

\section{AUTHOR'S CONTRIBUTION}

Conceptualization: Santos ER; Data Curation: Santos ER, Furuya HA, Junior ECB; Formal Analysis: Santos ER, Furuya HA, Junior ECB; Funding Acquisition: Santos ER, Junior ECB; Methodology: Santos ER, Junior ECB; Resources: Santos ER, Junior ECB; Software: Santos ER, Furuya HA, Junior ECB; Supervision: Santos ER, Junior ECB; Visualization: Santos ER, Furuya HA, Junior ECB; Writing - Original Draft: Santos ER, Furuya HA, Junior ECB; Draft Preparation: Santos ER, Furuya HA, Junior ECB; Writing - Review \& Editing: Santos ER, Furuya HA, Junior ECB.

\section{FUNDING}

Coordenação de Aperfeiçoamento de Pessoal de Nível Superior

http://doi.org/10.13039/501100002322

PNPD Project N02998/09-2

\section{DATA AVAILABILITY STATEMENT}

Data are available in a data repository. Furuya HA. Estudo de desempenho de lâmpadas LEDs [undergraduate thesis]. São Paulo: Faculdade de Tecnologia de São Paulo (FATEC-SP); 2020.

\section{REFERENCES}

1. Rogach AL. Towards next generation white LEDs: optics electronics synergistic effect in a single-layer heterophase halide perovskite. Light: Sci Appl. 2021;10:46. https://doi.org/10.1038/s41377-021-00488-8

2. Górecki K, Ptak P. Compact modelling of electrical, optical and thermal properties of multi-colour power LEDs operating on a common PCB. Energies. 2021;14(5):1286. https://doi.org/10.3390/en14051286

3. Feng S-W, Wang $\mathrm{Y}-\mathrm{H}$, Tsai C-Y, Cheng $\mathrm{T}-\mathrm{H}$, Wang $\mathrm{H}-\mathrm{C}$. Enhancing carrier transport and carrier capture with a good current spreading characteristic via graphene transparent conductive electrodes in InGaN/GaN multiplequantum- well light emitting diodes. Sci Rep. 2020;10:10539. https://doi.org/10.1038/s41598-02067274-1

4. Kotabage C. Is a glowing LED meaningful to determine Planks constant accurately? In: Fifteenth Conference on Education and Training in Optics and Photonics, Quebec City, Canada. Proceedings. 2019;111432S. http://doi. org/10.1117/12.2508193

5. Lee WJ, Fang Y-K, Ho J-J, Chen C-Y, Chiou L-H, Wang S-J, et al. Organic light-emitting diode on indium zinc oxide film prepared by ion assisted deposition dc sputtering system. Solid State Electron Lett. 2002;46(4):477-480. https://doi.org/10.1016/S0038-1101(01)00307-0

6. Lam SE, Nawi SNM, Sani SFA, Khandaker UM, Bradley DA. Raman and photoluminescence spectroscopy analysis of gamma irradiated human hair. Sci Rep. 2021;11:7939. https://doi.org/10.1038/s41598-021-86942-4

7. Marteleto DC. Avaliação do diodo emissor de luz (LED) para iluminação de interior [bachelor in Electrical Enginnering]. Rio de Janeiro: Universidade Federal do Rio de Janeiro; 2011 
8. Hortilux. Evaluating the quality of a grow light using spectrum [Internet]. Hortilux [cited on July 8, 2021]. Available from: https://eyehortilux.com/grow-lighting-guide/measuring-light-for-plant-growth/evaluating-quality-growlight-using-spectrum/

9. Teixeira I, Rivera R, Reiff LO. Iluminação LED: sai Edison, entram Haitz e Moore - benefícios e oportunidades para o país. BNDES Setorial [Internet]. 2015 [cited on Sep., 2021];43:363-412. Available from: https://web.bndes.gov. br/bib/jspui/bitstream/1408/9576/2/BS\%2043\%20lluminação\%20LED\%20sai\%20Edison\%2C\%20entram\%20 Haitz\%20e\%20Moore_P_BD.pdf

10. Faria AC. Iluminação sustentável: os benefícios do uso da tecnologia LED nos projetos de iluminação [dissertation on the internet]. Goiânia: Pontifícia Universidade Católica de Goiás; 2014 [cited on Sep., 2021]. Available from: http://tede2.pucgoias.edu.br:8080/bitstream/tede/2548/1/ANA\%20CAROLINA\%20DE\%20FARIA.pdf

11. FazFácil. Lâmpadas LED - o que são? Diferenças e vantagens [Internet]. FazFácil [cited on July 8, 2021]. Available from: http://www.fazfacil.com.br/reforma-construcao/lampadas-led-o-que-sao/

12. Helio AF, Füllenbach TC. Estudo de desempenho de lâmpadas LEDs [undergraduate thesis in Microelectronic Technology]. São Paulo: FATEC-SP; 2020

13. Ázara I, Menegotto T, Gomes J. CCT determination using a method with automated iterative calculation. J Phys Conf Ser. 2021;1826:012061. http://doi.org/10.1088/1742-6596/1826/1/012061

14. Megaman. Megaman Colour Technology - Consistency [Internet]. Megaman [cited on July 8, 2021]. Available from: https://www.megamanuk.com/news/megaman-colour-technology-consistency/

15. Santos ER, Burini Junior EC, Hui WSH. Influence of temperature in the performance of the LED lamp. RBAV. 2020;39(2):156-67. https://doi.org/10.17563/rbav.v39i2.1171 